\title{
A APLICAÇÃO DAS DIRETIVAS ANTECIPADAS DE VONTADE NA PESSOA COM DEMENNCIA
}

\section{The application of advance directives and living will in persons with dementia}

\author{
Cláudia Burláa, Rui Manuel Lopes Nunes ${ }^{a}$
}

O crescente envelhecimento mundial é acompanhado pelo aumento da expectativa de vida, especialmente nas pessoas de idade mais avançada, expandindo o número de idosos com doenças cronicodegenerativas, dentre as quais se destaca a demência, notadamente a Doença de Alzheimer. Essas pessoas, que demandam tratamentos e cuidados especializados, apresentam-se como um desafio à prática médica, pela multidimensionalidade de questões implicadas na sua saúde, ressaltando-se a perda da capacidade cognitiva, com dano irreversível à autonomia, um princípio pilar da Bioética. Nesse cenário, realizamos este estudo, com o objetivo de, no desenvolvimento das buscas teóricas, proceder a uma investigação reflexiva sobre a perda de autonomia da pessoa com demência, considerando as Diretivas Antecipadas de Vontade — um instrumento de proteção e garantia da preservação quando já se encontrar incapacitada de expressar a sua vontade. O caminho metodológico é o da pesquisa qualitativa em saúde, centrado na investigação reflexiva, promovendo um diálogo entre fatos biomédicos e referenciais bioéticos. A revisão de literatura foi realizada em livros e em periódicos indexados dos últimos dez anos nas bases de dados do PubMed e LILACS. Discutimos a pertinência das Diretivas Antecipadas de Vontade como instrumento que representa um êxito da civilização atual ao priorizar a autonomia do indivíduo e lhe assegurar o exercício pleno da cidadania. Esse instrumento, se aplicado a idosos saudáveis, antecipa-se à possível instalação de dano cognitivo posterior, apontado pelos dados demográficos e epidemiológicos. No curso evolutivo da demência, mesmo na fase inicial, não é confiável o registro da legítima vontade da pessoa sobre o que quer ou não para si em termos de tratamento e cuidado. Finalizando o estudo, propomos uma articulação da Geriatria com a Bioética, em que profissionais qualificados possam orientar pessoas idosas e seus familiares a procederem a uma reflexão profunda sobre saúde e doença, autonomia e incapacidade, para assumirem a liberdade de fazerem valer a sua vontade num futuro incerto em que talvez não mais possam fazer essa escolha para si mesmo.

PALAVRAS-CHAVE: envelhecimento; idosos; demência; Doença de Alzheimer; autonomia; diretivas antecipadas de vontade; testamento vital.

The growth in world ageing is associated with an increase in life expectancy particularly in persons of more advanced ages, which expands the number of older persons with chronic-degenerative diseases, Alzheimer's disease in particular. Such individuals require specialized treatment and care. They challenge medical practice because they present multidimensional health conditions, notably cognitive impairment, which irreversibly compromises their autonomy, one of the pillars of Bioethics. In this context, this study was conducted so that, in proceeding with the search of theories, we could reflect on the loss of autonomy of the person with dementia, considering Advance Directives as an instrument provinding protection and assurance that the person's wishes will be complied with in the future. The methodology chosen was qualitative health research centered in a reflexive investigation, promoting a dialogue between biomedical facts and bioethical frameworks. For the review of literature, we examined to books and journals posted on PubMed and LILACS databases over the past 10 years. We have discussed the pertinence of Advance Directives as a successful construct of our civilization for prioritizing the autonomy of the individual and ensuring the full exercise of their rights as citizens. This instrument should be created by health older individuals prior to the development of cognitive impairment that may occur in keeping with demographic and epidemiological data. In the progressive course of dementia, even in its early stages, the recording of the person's wishes about what they want or not for themselves in terms of treatment and care is not reliable. In the conclusion of our study, we propose that Geriatrics and Bioethics be connected, so that qualified practitioners could guide older people and their family in an in-depth reflection about health and disease, autonomy and impairment, so that they can make their wishes count in an uncertain future, when they may no longer be able to make this choice themselves.

KEYWORDS: ageing; older people; dementia; Alzheimer's Disease; autonomy; advance directives; living will.

aFaculdade de Medicina, Universidade do Porto - Porto, Portugal.

Dados para correspondência

Cláudia Burlá - Rua Artur Araripe, 43/103, Gávea - CEP: 22451-020 - Rio de Janeiro (RJ), Brasil - E-mail: claudiaburla@gmail.com

Recebido em: 05/09/2017. Aceito em: 14/09/2017

DOI: 10.5327/Z2447-21152017201700066 